\title{
A Health Professional's Political Science Education: Lessons from a Congressional Fellowship
}

\author{
Nadine Braunstein, Towson University
}

$\mathrm{P}$ olitical science coursework is rarely required in the curricula for the health professions. My education and training to become a registered dietitian in the 1970 s was no exception. Although I lacked this formal training, being a 2013-2014 APSA Congressional Fellow through the Robert Wood Johnson Foundation (RWJF) Health Policy Fellows program allowed me to receive a real-world, hands-on political science education.

\section{FOOD AND HEALTH POLICY EXPERIENCE PRIOR TO THE FELLOWSHIP}

Several experiences before the fellowship provided an entry point into my political education. When I served as president of the Massachusetts Dietetic Association (MDA) in the 1990s, I had the opportunity to attend my professional association's public policy workshop in Washington, DC, make Hill visits to the offices of then-congressman Barney Frank (D-MA), meet with the late congressman Joe Moakley (D-MA) (then chair of the House Rules Committee), and give an award the late senator Edward Kennedy (D-MA) in his Boston office. At that time, dietitians in Massachusetts did not have licensure, so there were hearings on Beacon Hill where I gave testimony on behalf of MDA. This was the start of my political education.

In 2009 when I arrived at Towson University, there was a strong relationship between the university and the Cherry Hill neighborhood of Baltimore. I attended a community/university meeting to introduce people from both stakeholder groups to determine possible areas of collaboration. Cherry Hill, a geographically isolated area of Baltimore, did not have a grocery store and had some of the poorest health indicators in the city. Baltimore City defines a "Food Desert" as "an area where the distance to a supermarket is more than $1 / 4$ mile, the median household income is at or below $185 \%$ of the Federal Poverty Level, over $40 \%$ of households have no vehicle available, and the average Healthy Food Availability Index score for supermarkets, convenience, and corner stores is low (measured using the Nutrition Environment Measurement Survey)" (Baltimore City 2015). Community members were interested in improving food access options for Cherry Hill. Ms. Juanita Brown-Ewell, a life-long resident of the community, had a vision to bring healthy food to Cherry Hill, primarily by starting an urban farm on land that had been the site of public housing. Over several years, grants were obtained to start the Cherry Hill "Eat Healthy Live Healthy" Urban Garden, and partnerships formed with stakeholders including with the Farm Alliance of Baltimore and the Baltimore City Food

Nadine Braunstein is an assistant professor at Towson University, Towson, Maryland, where she is the Allied Health Program Director in the College of Health Professions. She can be reached at Nadinebraunstein@gmail.com.
Policy Advisory Committee. Food now has been harvested and sold to residents of Cherry Hill and at other farmers' markets for over three years. The experience of assisting the Cherry Hill community improve its food access issues led to professional relationships in food and health policy in Baltimore.

A new "Core Curriculum" was being instituted at Towson University in 2011, and faculty members were invited to create freshmen seminar courses. I proposed "Food Politics: Agriculture, Industry, Policy, and Health." My connections with stakeholders in the food policy community in Baltimore led to invitations for guest speakers and class research projects. One of these projects was solicited by Baltimore's food policy director to complete a transit study to determine the time it would take to get from public housing located in food deserts to the nearest grocery store if a resident used public transportation. Students crowd-sourced their research using www. transit.google.com, then presented the results to city officials. It brought to life the intersections of food access, policy, and transportation for the students. These prior experiences provided the health policy foundation that I described in my 2013 application to be a RWJF Health Policy Fellow.

\section{FELLOWSHIP}

Every aspect of the RWJF fellowship experience led to growth and deepened my understanding of health policy and politics. The application process helped me focus and refine my explanation of why I wanted to be involved in health policy now. President Obama was re-elected just before the applications were due. Because Mrs. Obama's interest has been good nutrition, it seemed that there would be a window of at most two years remaining to capitalize on the momentum. RWJF has also committed substantial resources to promoting health and nutrition, which made the timing of my application an important factor because the RWJF fellowship had not selected a registered dietitian (RD) in over 30 years. It was my good fortune to be one of two RDs in my cohort of six fellows.

The orientations for RWJF and the APSA Congressional Fellowship Program provided access to important leaders in health policy and political science. The meetings with alumni of both programs proved very useful during the entire fellowship. Alumni provided insights, mentoring, and valuable networks for the fellows. As the weeks progressed, the current fellows (or as we called each other, "fellow fellows") became a close network for each other. We often met for happy hours, at congressional hearings, and for coffee to exchange ideas and tales of our placement experiences. The networks of current fellows, alumni, and the speakers were a solid support system throughout the fellowship. We also used these contacts when seeking technical assistance and co-sponsors for legislation, signatures for "Dear Colleague" letters, and for presenters when 
the Canadian Parliamentary Interns came to Washington, DC, for their exchange.

Nearly all of the APSA residential fellows contributed to the planning of or attended one of the events we scheduled for the Canadians' weeklong exchange. Using our networks (including those of our fellowship cohort), we joined our guests for lunch at the Canadian Embassy, tours of the Federal Reserve Bank and the Pentagon, a riverboat tour of Washington, DC, and a guided tour of the Capitol; meetings with Congressman Grijalva (see the article written by 2013-14 fellow Sa-ngopkarn Moungthong), ${ }^{1}$ a lobbyist, and congressional leadership; meetings at the State Department, the White House Office of Intergovernmental Affairs, the Wilson Center, think tanks, the Institute of Medicine, the Foreign Press Center, Democratic National Committee, and the US Chamber of Commerce; and a meeting of "Space Advocates," a registered congressional staff organization.

The Canadians hosted us with an equally impressive week that included meetings with top government leaders, a Canadian Supreme Court justice, and a leader from Canada's Assembly of First Nations. Many high-level officials spoke with us frankly and in-depth about his budget, I led the outreach for signatures requesting funding for elder justice programs, increasing the signers from the year before. In the 112th Congress, Senator Blumenthal had introduced elder justice legislation, and I obtained technical assistance from experts, advocates, and crafters of prior elder justice legislation, working across the aisle with potential co-sponsors to update and integrate changes with the plan to introduce new legislation. Even though that bill wasn't introduced during the 113th Congress, the extensive background work provided groundwork for future legislation. One staffer I met during that process had worked for nearly 10 years on the elder justice bill that eventually was incorporated into the Affordable Care Act. She said that writing legislation is a very creative process, which was something that I had not thought of prior to that conversation.

A few weeks after I began, I was able to take on veterans issues, as well, working with the Legislative Director, in addition to working with the health LA. No one could have predicted the prominence of the Veterans' Affairs (VA) Committee during the 113th Congress that emerged after the scheduling scandal at the Phoenix VA. I sat behind the senator for numerous hearings with veterans' service organiza-

\section{My most satisfying political experience was working across the aisle with an LA from sena- tor Jerry Moran's office $(R-K S)$... . It was a true collaboration and demonstrated how work- ing across the aisle on issues that have bi-partisan support can yield results.}

many facets of the country. My understanding about the politics, healthcare, military, First Nations, international relations, and energy issues in Canada was minimal prior to the exchanges, and grew exponentially by the end of the fellowship.

When we learned of the Ottawa shootings on Parliament Hill in October 2014, our visit of fewer than six months prior made what we were hearing on the news very personal. We had walked the halls of Parliament and knew exactly the locations being described in the news. Several of the fellows reached out to our friends in Ottawa to check on the safety and well-being of the staff and interns. We were happy to learn from their program director that all were safe, though a bit shaken, by the experience.

\section{PLACEMENT EXPERIENCE}

I interviewed in three congressional offices, and then learned that senator Richard Blumenthal's office (D-CT) would be interested in having a fellow. I interviewed there on the Friday before the Christmas break and was offered a position. The process of interviewing with multiple offices was very beneficial because the health legislative assistants (or LAs) who conducted the interviews were the same people we would see at hearings and meetings throughout the fellowship placement.

I was very fortunate to be given the opportunity to work with the staff of Senator Blumenthal's office. On the very first day in the office, the health LA had projects for me to do. During the placement, I worked on issues where I had some expertise, including organizing and speaking at a brown bag lunch panel about the Food Labeling Modernization Act, which Senator Blumenthal had introduced. Michael Jacobson from the Center for Science in the Public Interest, one of the foremost leaders in nutrition advocacy, was also on the panel.

During the appropriations period after the president proposed tions, attended special closed-door briefings and private meetings, and worked closely with the Senate Veterans' Affairs majority staff during the negotiations for several iterations of legislation that became the Veterans Access, Choice, and Accountability Act of 2014.

My most satisfying political experience was working across the aisle with an LA from senator Jerry Moran's office (R-KS). In March, the Vietnam Veterans of America (VVA) held a briefing to promote the Toxic Exposure Research and Military Family Support Act of 2013, introduced by Senator Blumenthal. This bill would have provided funding for a research center to study veterans who had toxic

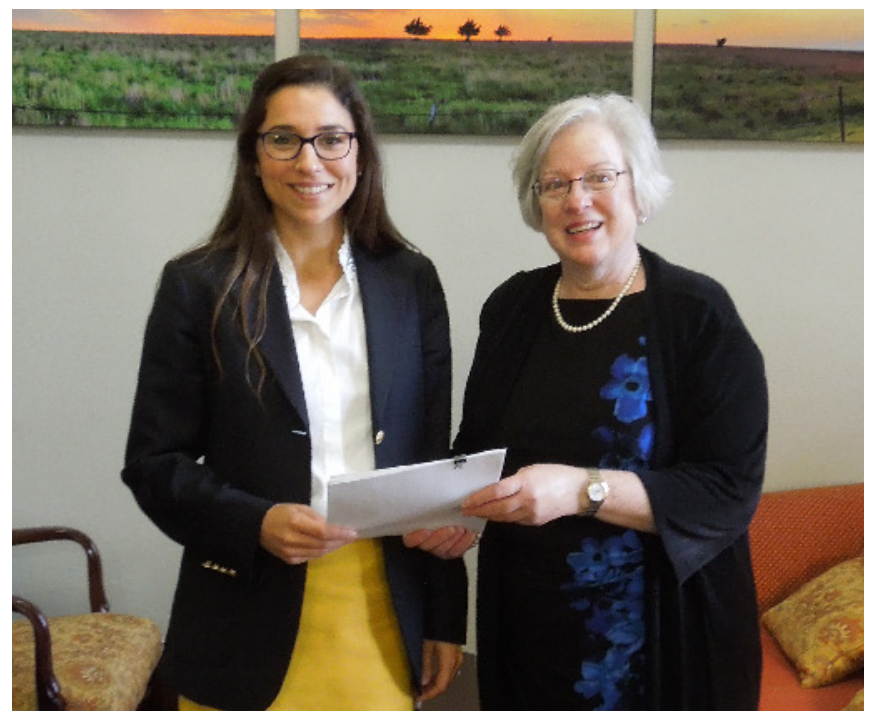

The author (right) pictured with Caroline Prosch (left), a legislative assistant from the office of senator Jerry Moran (R-KS) that helped craft bi-partisan bill S. 2738, the Toxic Exposure Research Act of 2014. 
exposures, as well as payment to care for several generations of their offspring. Following this event, we began to collaborate with staff from Senator Moran's office, and by July 31 we had worked closely with VVA to introduce a new bill, S. 2738, the Toxic Exposure Research Act of 2014. It was a true collaboration and demonstrated how working across the aisle on issues that have bipartisan support can yield results. Even though the bill did not become law, it can be reintroduced in the future. I learned that legislation gets revised and reintroduced over many congressional sessions before it becomes law. Hopefully, for the veterans who have been exposed to toxic chemicals during their service to our country, a bill similar to the one I helped craft will become law one day.

\section{AFTER THE CONGRESSIONAL PLACEMENT}

I was fortunate to have the opportunity to extend my experience in Washington, DC, beyond the 12-month fellowship year and be placed in an executive branch agency for an additional four months. My expertise as a registered dietitian was utilized at the Department of Health and Human Services (HHS) Office of Disease Prevention and Health Promotion, where I supported the staff working with the 2015 US Dietary Guidelines Advisory Committee (DGAC). This process happens once every five years, so my timing was perfect to learn about the dietary guidelines process.

I was appointed subsequently as the vice chair of the Licensure and Public Policy Committee of the Academy of Nutrition and Dietetics, my professional association, largely because of my experiences in the Senate and at HHS. In the short time serving on this committee, it was clear that my understanding of the legislative and policy pro- cesses was so much greater than it had been before the fellowship.

In January, 2015, I returned to Towson University, where I am sharing my fellowship experiences with the Food Politics Freshman Seminar students. People I met during the fellowship are now guest speakers, including LAs and lobbyists. I am also integrating issues of veterans' health in the Professional Issues in Allied Health course, and I hope to offer a veterans' health seminar. Several colleagues have invited me to give guest lectures to inform their students about health and nutrition policy. And there are journal articles in progress based upon some aspects of the HHS experience.

A brief article such as this only skims the surface of my RWJF and APSA Congressional Fellowship experiences. Students will be regaled with stories of my political science education for many semesters. And perhaps some small contribution I made while working in the Senate or at HHS, or will make as a result of something learned during the fellowship, will help improve the health of the nation.

\section{NOTES \\ 1. Moungthong, Sa-ngopkarn. 2014. "Capitol Hill Culture Shock: A Perspective from an Asian Fellow." PS: Political Science \& Politics 47(3) 764-66. doi:10.1017/ S1049096514001036.}

\section{REFERE N C ES}

Baltimore City. 2015. Planning/Baltimore Food Policy Initiative/Food Deserts. Retrieved February 3, 2015, from http://archive.baltimorecity.gov/Government/ AgenciesDepartments/Planning/BaltimoreFoodPolicyInitiative/FoodDeserts. aspx.

\section{APSA Congressional Fellowship Program Office Assignments 2014-2015}

$\mathrm{F}$ ounded in 1953, the APSA Congressional Fellowship Program is the nation's oldest and most prestigious congressional fellowship. More than 60 years later, the program remains devoted to its original objective of expanding knowledge and awareness of Congress. For nine months, select political scientists, journalists, doctors, federal executives, and international scholars gain "hands on" understanding of the legislative process by serving on congressional staffs. Through this unique opportunity, the association enhances public understanding of policy making and improves the quality of scholarship, teaching, and reporting on American national politics. For more information about the program visit https://www.apsanet.org/cfp. The assignments for 2014-15 are listed below.

\section{US HOUSE OF REPRESENTATIVES}

Laura Blessing

Rep. Lloyd Doggett (D-TX)

Mary Bodine

Rep. Peter DeFazio (D-OR)

Marian Grant

Rep. Nancy Pelosi (D-CA)

Alexandra Hadley

Rep. Cheri Bustos (D-IL)

Lael Herbert

Rep. Mike Honda (D-CA)

\section{Patti Jenkins}

Rep. Betty McCollum (D-MN)

Nicha Pitayathornpitaksa

Rep. Danny K. Davis (D-IL)

US SENATE

Karen Armitage

Sen. Sheldon Whitehouse (D-RI)

Benjamin Canavan

Sen. Orrin Hatch (R-UT)
Elizabeth C. Burdick

Sen. Timothy Kaine (D-VA)

Colleen Leners

Sen. John Thune (R-SD)

Paulina Rippere

Sen. Jack Reed (D-RI)

\section{COMMITTEES}

Karen Matthews

Senate Finance Committee (Minority) 
Anh T. Nguyen

Senate Health, Education, Labor and Pensions Committee (Majority)

\section{Elizabeth Rigby}

Senate Finance Committee (Minority)

\section{Jonathan Swan}

House Foreign Affairs Committee

(Majority)

\section{EXECUTIVE BRANCH}

Heidi Allen

Health and Human Services, Office of the Assistant Secretary for Planning and Evaluation

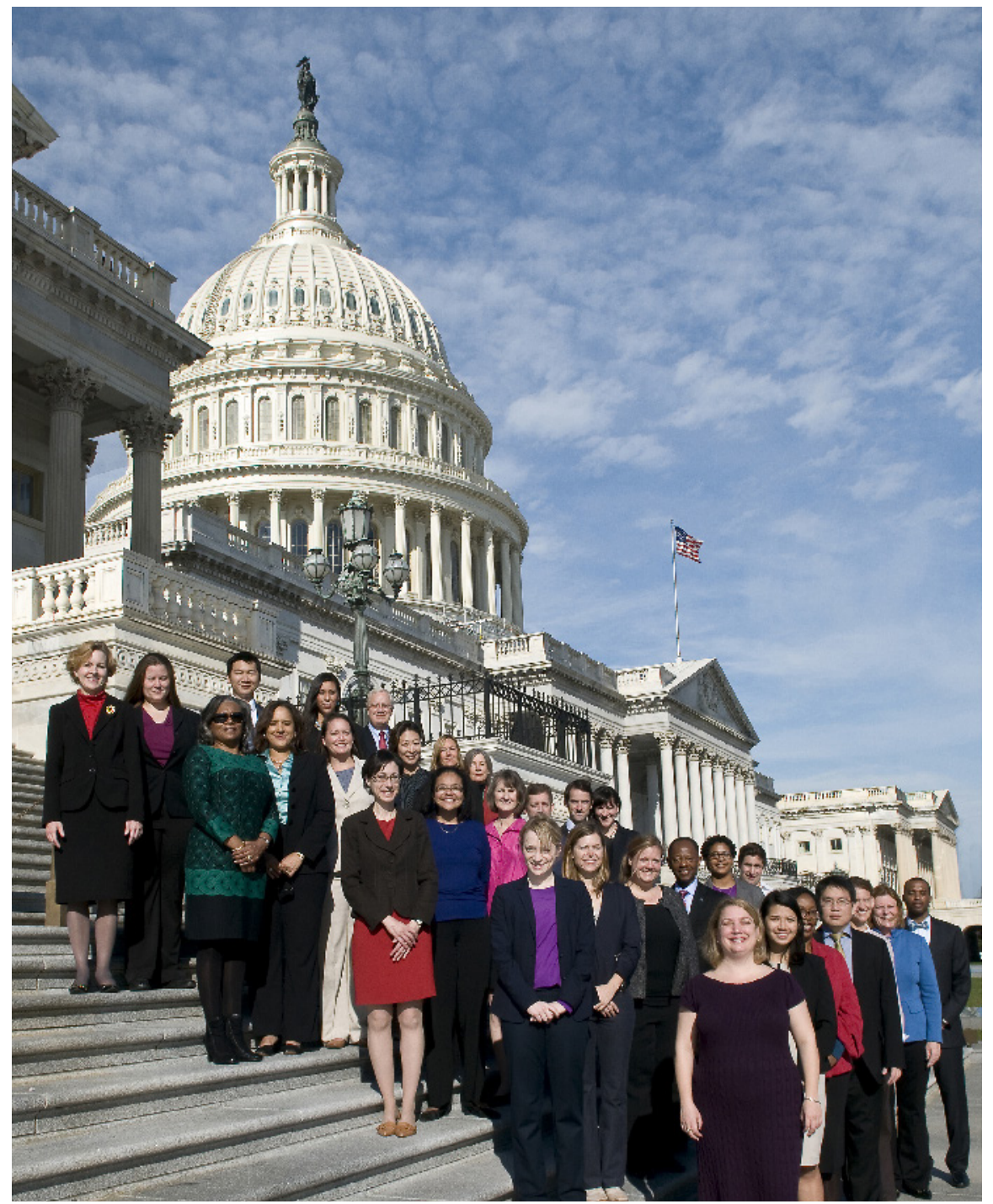

Pictured are the 2014-15 APSA Congressional Fellows. Row 1: Amy Dahm, Vorada Savengseuksa, Shirley Bondon, William Hung, Victoria Walker, Colleen Leners, Lael Herbert; Row 2: Rachel Roiland, Heidi Allen, Elizabeth Rigby, Lemuel Dent, Alexandra Hadley, Jonathan Swan; Row 3: Kara Abramson, Kimberlyn Leary, Marian Grant, Jason Johanning, Benjamin Canavan, Elizabeth Burdick; Row 4: Veronica Long, Beverly Xaviera Watkins, Paulina Rippere, Patricia Yu, Karen Matthews, Karen Armitage; Row 5: Patti Jenkins, Laura Blessing, Thomas Tsai, Mary Bodine, Rick Selvik

\section{Shirley Bondon}

Health \& Human Services, Administration for Community Living

\section{Lemuel Dent}

Department of Defense, Office of the Assistant Secretary of Defense for Health Affairs

\section{William Hung}

Health and Human Services, Office of the National Coordinator for Health Information Technology

\section{Jason Johanning}

Department of Veterans Affairs, Office of Geriatrics and Extended Care Services

\section{Kimberlyn Leary}

White House Council on Women and Girls

Amanda Lehning

Office of the Surgeon General

Rachel Roiland

Department of Veterans Affairs, Office of Geriatric and Extended Care Services

\section{Vorada Savengseuksa}

Centers for Medicare and Medicaid, Office Medicare-Medicaid Coordination Office

Rick Selvik

Geriatric Workforce Enhancement Program

\section{Lori Simon-Rusinowitz}

Health and Human Services, Administration for Community Living

Thomas Tsai

Health and Human Services, Office of the Assistant Secretary for Planning and Evaluation

\section{Victoria Walker}

Centers for Medicare and Medicaid, Office of Clinical Standards and Quality / Altarum Institute

\section{Patricia Yu}

White House Conference on Aging 